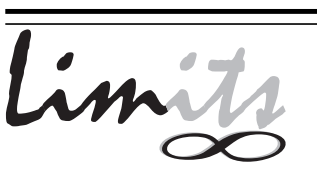

J. Math. and Its Appl.

ISSN : $1829-605 \mathrm{X}$

Vol. 6, No. 1, May 2009, 49-59

\title{
Aljabar Maxplus dan Aplikasinya : Model Sistem Antrian
}

\author{
Subiono \\ Jurusan Matematika \\ FMIPA ITS, Surabaya \\ subiono2008@matematika.its.ac.id
}

\begin{abstract}
Abstrak
Dalam paper ini dibahas pengertian dari aljabar maxplus dan beberapa sifat-sifatnya serta diberikan suatu contoh aplikasi dari aljabar maxplus. Selanjutnya dibahas suatu model sistem antrian satu server dalam aljabar maxplus. Katakunci: Aljabar Maxplus, sistem antrian.
\end{abstract}

\section{Pendahuluan}

Sebagian phenomena dari sistem manufaktur, jaringan telekomonikasi dan sistem transportasi bisa dijelaskan oleh Sistem Even Diskrit (SED). Hal ini tentunya sesuai dengan keadaan saat ini baik bagi dunia industri ataupun dunia akademik yang tertarik pada teknik untuk memodel, menganalisa dan mengontrol sistem yang kompleks seperti sistem manufaktur, jaringan telekomunikasi, sistem proses parallel, sistem kontrol trafik lalin, sistem logistik dsb. Macam-macam sistem yang telah di sebutkan tadi adalah contoh-contoh dari Sistem Event Diskrit (SED). Suatu gambaran karakteristik dari SED adalah 'kedinamikannya' yaitu "event-driven" hal ini bertolak belakang dengan "time-driven". Disini perilaku suatu SED lebih ditentukan oleh event dari pada waktu. Suatu event berkaitan dengan 
awal atau akhir dari suatu aktifitas. Bila kita tinjau suatu sistem produksi, maka event yang mungkin adalah kelengkapan mesin telah menyelesaikan suatu produk, suatu buffer telah kosong dsb. Event terjadi dengan waktu diskrit. Interval diantara event tidak harus identik, bisa deterministik atau stokastik.

Suatu pengantar yang berkaitan dengan SED bisa didapat di [3]. Teknik yang paling luas digunakan untuk menganalisa SED adalah simulasi komputer. Kekurangan utama dari simulasi adalah ia sering tidak memberikan suatu pengertian yang nyata bagaimana parameter mengubah akibat penting sifat-sifat sistem, seperti kestabilan, kerobasan dan keoptimalan dari perilaku sistem. Oleh karena itu, metoda formal dibutuhkan sebagai alat untuk pemodelan, analisa dan kontrol bagi SED.

Pendekatan aljabar maxplus mengijinkan kita untuk menentukan dan menganalisa berbagai sifat sistem, tetapi pendekatan hanya bisa diterapkan pada sebagian klas SED yang bisa diuraikan dengan model waktu invarian max-linier. Subklas ini adalah subklas dari waktu invarian SED deterministik yang dapat digunakan untuk menganalisa perilaku suatu sistem yang ada. Pembahasan yang medalam tentang aljabar maxplus bisa dilihat di [1], sedangkan beberapa hasil dari aljabar maxplus dapat ditemui di [2].

Beberapa gambaran konkrit dari pemakaian aljabar maxplus adalah pada suatu jaringan sistem transportasi kereta di $[4,8]$, pemakaian pada proses produksi perakitan di [7]. Ditinjau dari sistem model yang dibahas dalam konteks aljabar maxplus adalah linear sedangkan dalam aljabar biasa non-linier ([6]), kelinieran ini tentunya akan memudahkan dalam penganalisaan sistem yang dikaji.

Sebagai motifasi, pada bagian berikutnya dalam paper ini akan diberikan suatu contoh pemakaian dari aljabar maxplus, yaitu yang berkaitan dengan suatu jadual yang periodik. Terutama bila hal ini dikaitkan dengan pengertian nilai-karakteristik dan vektor karakteristik dari suatu matriks persegi dalam aljabar maxplus. Untuk memperoleh nilai-karakteristik dan vektor karakteristik dari suatu matriks persegi dalam aljabar maxplus digunakan perangkat lunak Scilab 5.1.1. Perangkat lunak Scilab yang dipakai menggunakan Max-Plus Algebra Toolbox for Scilab ([9]). Namum sebelumnya diperkenalkan secara ringkas pengertian dari aljabar maxplus serta beberapa notasi yang digunakan. Selanjutnya dibahas penurunan mo- 
del antrian satu server dalam aljabar maxplus. Sebagai penutup diberikan beberapa catatan dari apa yang dibahas dan kajian/penelitian yang sedang dilakukan dan kedepannya.

\section{Aljabar maxplus dan bebeberapa notasi yang terkait.}

Dalam bagian ini, diberikan secara singkat pengenalan konsep dasar dari aljabar maxplus yang akan digunakan untuk pembahasan berikutnya. Elemen dari aljabar maxplus adalah bilangan real dan $\varepsilon=-\infty$. Selanjutnya himpunan $\mathbb{R} \cup\{\varepsilon\}$ ditulis sebagai $\mathbb{R}_{\max }$ dengan $\mathbb{R}$ adalah himpunan bilangan real. Operasi dasar dari aljabar maxplus adalah maksimum (dinotasikan dengan simbol $\oplus$ ) dan tambah (dinotasikan dengan simbol $\otimes$ ). Dengan dua operasi tersebut untuk setiap $x, y \in \mathbb{R}_{\max }$, didapat

$$
x \oplus y=\max (x, y) \quad \text { dan } \quad x \otimes y=x+y .
$$

Selanjutnya, dalam konteks aljabar maxplus $a^{\otimes^{b}} \stackrel{\text { def }}{=} a b$. Catatan: $x \oplus \varepsilon=$ $x=\varepsilon \oplus x$ dan $0 \otimes x=x=x \otimes 0$ untuk semua $x \in \mathbb{R}_{\max }$. Operasi $\oplus$ dan $\otimes$ diperluas ke matriks sebagai berikut: untuk $A, B \in \mathbb{R}_{\max }^{m \times n}$

$$
(A \oplus B)_{i j}=a_{i j} \oplus b_{i j}=\max \left(a_{i j}, b_{i j}\right), i=1,2, \ldots, m, \quad j=1,2, \ldots, n
$$

dan untuk $A \in \mathbb{R}_{\max }^{m \times p}, B \in \mathbb{R}_{\max }^{p \times n}$

$$
(A \otimes B)_{i j}=\bigoplus_{k=1}^{p} a_{i k} \otimes b_{k j}=\max _{k}\left(a_{i k}+b_{k j}\right), i=1,2, \ldots, m, j=1,2, \ldots, n .
$$

Dipilihnya simbol $\oplus$ dan $\otimes$ dalam aljabar maxplus adalah ada analogi diantara $\oplus$ dengan + dan $\otimes$ dengan $\times$. Disini terlihat perkalian dua matriks mirip dengan perkalian dua matriks dalam aljabar biasa yaitu, perkalian dua matriks dalam aljabar biasa menggunakan operasi "kali" dan "tambah" sedangkan perkalian dua matriks dalam aljabar maxplus menggunakan operasi "tambah" dan "maksimum" masing-masing sebagai ganti dari operasi "kali" dan "tambah" yang digunakan pada perkalian dua matriks dalam aljabar biasa. Dengan menggunakan simbol-simbol tsb. diskripsi ruang keadaan suatu sistem diberikan dalam bentuk: 


$$
\left.\begin{array}{rl}
x(k+1) & =A \otimes x(k) \oplus B \otimes u(k) \\
y(k) & =C \otimes x(k)
\end{array}\right\}
$$

Pengertian nilai-karakteristik dan vektor-karakteristik yang bersesuaian dari suatu matriks persegi $A$ berukuran $n \times n$ sebagaimana dijumpai dalam aljabar linear biasa juga dijumpai dalam aljabar maxplus, yaitu bila diberikan suatu persamaan:

$$
A \otimes x=\lambda \otimes x
$$

dalam hal ini masing-masing vektor $x \in \mathbb{R}_{\max }^{n}$ dan $\lambda \in \mathbb{R}$ dinamakan vektorkarakteristik dan nilai-karakteristik dari matriks $A$ dengan vektor $x \neq(\varepsilon, \varepsilon, \ldots, \varepsilon)^{\prime}$. Tanda ' yang telah digunakan menyatakan transpose. Suatu algoritma untuk memperoleh vektor-karakteristik dan nilai karakteristik dari matriks persegi $A$ bisa ditemui di [5].

Contoh 2.1 Diberikan matriks

$$
A=\left(\begin{array}{ccc}
5 & \varepsilon & 5 \\
\varepsilon & 6 & 3 \\
6 & 6 & 3
\end{array}\right) \text {, didapat }\left(\begin{array}{ccc}
5 & \varepsilon & 5 \\
\varepsilon & 6 & 3 \\
6 & 6 & 3
\end{array}\right) \otimes\left(\begin{array}{l}
0 \\
1 \\
1
\end{array}\right)=6 \otimes\left(\begin{array}{l}
0 \\
1 \\
1
\end{array}\right) .
$$

Misalkan matriks $A \in \mathbb{R}_{\max }^{n \times n}$, suatu grap berarah dari matriks $A$ adalah $\mathcal{G}(A)=(E, V)$. Grap $\mathcal{G}(A)$ mempunyai $n$ titik, himpunan semua titik dari $\mathcal{G}(A)$ dinyatakan oleh $V$. Suatu garis dari titik $j$ ke titik $i$ ada bila $a_{i j} \neq \varepsilon$, garis ini dinotasikan oleh $(j, i)$. Himpunan semua garis dari grap $\mathcal{G}(A)$ dinotasikan oleh $E$. Bobot dari garis $(j, i)$ adalah nilai dari $a_{i j}$. Bila $a_{i j}=\varepsilon$, maka garis $(j, i)$ tidak ada. Suatu barisan garis $\left(i_{1}, i_{2}\right),\left(i_{2}, i_{3}\right), \ldots,\left(i_{l-1}, i_{l}\right)$ dari suatu grap dinamakan suatu path. Suatu path dikatakan elementer bila tidak ada titik terjadi dua kali dalam path tsb. Suatu sirkuit adalah path elementer tertutup, yaitu $\left(i_{1}, i_{2}\right),\left(i_{2}, i_{3}\right), \ldots,\left(i_{l-1}, i_{1}\right)$. Bobot dari suatu path $p=\left(i_{1}, i_{2}\right),\left(i_{2}, i_{3}\right), \ldots,\left(i_{l-1}, i_{l}\right)$ diberikan oleh $\left(a_{i_{2}, i_{1}}+a_{i_{3}, i_{2}}+\right.$ $\left.\ldots+a_{i_{l}, i_{l-1}}\right)$, sedangkan bobot rata-ratanya adalah bobot dari $p$ dibagi oleh banyaknya garis dalam path $p$, yaitu $\left(a_{i_{2}, i_{1}}+a_{i_{3}, i_{2}}+\ldots+a_{i_{l}, i_{l-1}}\right) /(l-1)$. Sirkuit mean adalah bobot rata-rata dari suatu sirkuit. Sebarang sirkuit dengan sirkuit mean maksimum dinamakan sirkuit kritis. Suatu grap dikatakan strongly connected bila suatu path ada untuk setiap titik $i$ ke setiap titik $j$. 


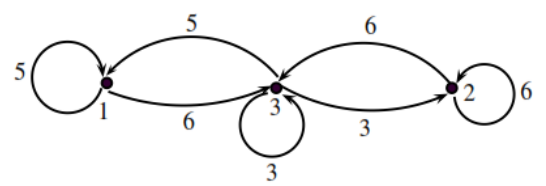

Gambar 1: Sistem pegas

Gambar grap $\mathcal{G}(A)$ dari Contoh 2.1 diberikan dalam Gambar ??. Dalam gambar ini ada lima sirkuit yaitu $(1,1) ;(1,3),(3,1) ;(3,3) ;(2,3),(3,2)$ dan $(2,2)$. Masing-masing sirkuit mempunyai sirkuit mean $5 / 1=5,(6+5) / 2=$ $\frac{11}{2}, 3 / 1=3,(6+3) / 2=\frac{9}{2}$ dan $6 / 1=6$. Terlihat bahwa sirkuit mean maksimum adalah 6 terjadi pada sirkuit $(2,2)$. Jadi sirkuit kritis dari grap $\mathcal{G}(A)$ adalah sirkuit $(2,2)$. Juga tampak bahwa grap $\mathcal{G}(A)$ adalah strongly connected. Beberapa pengertian dan sifat yang dibahas ini telah diimplementasikan dalam suatu toolbox ([9]). Intepretasi dari nilai-karakteristik dan vektor-karakteristik dalam Contoh 2.1 adalah sebagai berikut: Misalkan ada tiga aktifitas yang beroperasi secara periodik. Diasumsikan bahwa aktifitas ini beroperasi tidak secara bebas dan output dari satu aktifitas menjadi input aktifitas tertentu lainnya. Satu aktifitas hanya bisa dimulai bila beberapa aktifitas tertentu lainnya sudah menyelesaikan pekerjaannya dan mengirimkan hasilnya ke aktifitas yang ditentukan. Jadi satu aktifitas tertentu hanya bisa memulai kegiatannya pada saat yang ke- $(k+1)$ bila beberapa aktifitas yang lainnya telah menyelesaikan kegiatannya pada saat yang ke- $k$ dan mengirimkan hasilnya keaktifitas tsb. Elemen $a_{i j}$ dari matriks $A$ menunjukkan waktu tunggu dari aktifitas $i$ untuk memulai kegiatannya saat yang ke- $(k+1)$ setelah aktifitas $j$ menyelesaikan kegiatannya dan mengirimkan hasilnya ke aktifitas $i$ pada saat yang ke- $k$. Bila elemen $a_{i j}=\varepsilon$, maka hal ini menunjukkan bahwa aktifitas $i$ tidak bergantung pada aktifitas $j$.

Selanjutnya evolusi sistem dalam Contoh 2.1 diberikan oleh persamaan

$$
x(k+1)=A \otimes x(k), k=0,1,2, \ldots .
$$

Bila dipilih $x(0)$ adalah vektor-karakteristik dari matriks $A$, maka sistem (2) akan beroperasi secara periodik dengan periode sebesar nilai-karakteristik 
$\lambda=6$. Hal ini sesuai dengan bentuk persamaan berikut :

$$
x(k+1)=A \otimes x(k)=\lambda^{\otimes^{(k+1)}} \otimes x(0), k=0,1,2, \ldots .
$$

Sehingga didapat barisan aktifitas $x(k)$ :

$$
\left(\begin{array}{l}
0 \\
1 \\
1
\end{array}\right),\left(\begin{array}{l}
6 \\
7 \\
7
\end{array}\right),\left(\begin{array}{l}
12 \\
13 \\
13
\end{array}\right),\left(\begin{array}{l}
18 \\
19 \\
19
\end{array}\right), \ldots
$$

Berikut ini diberikan pengertian dari Petri net yang digunakan dalam pembahasan berikutnya terutama bila Petri net ini dikaitkan dengan waktu. Suatu grap $\mathcal{G}=(E, V)$ dikatakan bipartisi bila himpunan titik-titik $V$ dapat dipartisi menjadi dua himpunan bagian yang saling asing $V_{1}$ dan $V_{2}$ sedemikian hingga setiap garis di $\mathcal{G}$ menghubungkan suatu titik dari $V_{1}$ ke satu titik $V_{2}$ begitu juga sebaliknya. Petri net adalah grap bipartisi. Himpunan $V$ dipartisi menjadi dua himpunan bagian $P$ dan $T$ yang masing-masing menyatakan place dan transisi. Suatu place $p \in P$ dan suatu transisi $t \in P$ dapat diintepretasikan sebagai suatu kondisi dan suatu event dari suatu diskripsi suatu model yang dibahas. Masing-masing kondisi $p \in P$ yang 'terpenuhi' diberi tanda titik (token). Suatu token dalam suatu place mempunyai arti bahwa sepanjang place ini penting bagi suatu transisi yang dihubungkannya menyebabkan transisi ini menjadi aktif (event bisa berlangsung). Jadi dengan dua, tiga, empat, ... token, event ini bisa berlangsung dua, tiga, empat, ... kali. Untuk memperjelas pengertian ini diberikan suatu contoh Petri net dari suatu model sistem antrian sederhana dengan satu server. Contoh ini akan dibahas lagi terutama bila Petri net dari sistem antrian sederhana dengan satu server ini dikaitkan dengan waktu (Petri netnya dinamakan Petri net dengan waktu). Selanjutnya diturunkan bentuk modelnya dari Petri net dengan waktu ini dalam aljabar maxplus. Gambar dari sistem antrian sederhana dengan satu server beserta Petri netnya (Petri net tanpa waktu) diberikan sebagi berikut.

Dalam Gambar 2 bagian (i), a menyatakan kedatangan pelanggan menuju sistem antrian sedangkan d menyatakan pelanggan telah dilayani oleh server dan meninggalkannya. Sedangkan Gambar ?? bagian (ii) merupakan 


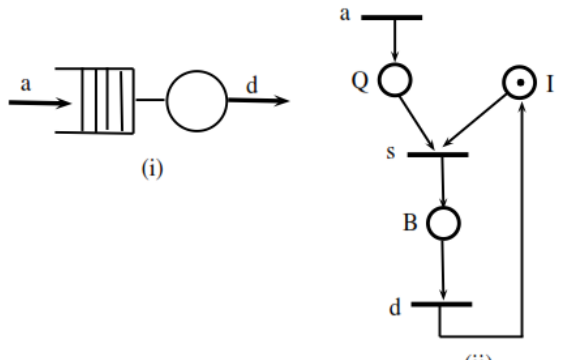

(ii)

Gambar 2: Sistem pegas

penyajian Petri net dari sistem antrian pada bagian (i). Petri net ini terdiri dari himpunan place $P=\{Q, B, I\}$ dan himpunan transisi $T=\{a, s, d\}$. Masing-masing place $Q, B$ dan $I$ menyatakan kondisi antri, sibuk dan idel. Sedangkan transisi $a, s$ dan $d$ masing-masing menyatakan event kedatangan, mulai dilayani dan meninggalkan server. Tanda satu token dalam place I menyatakan bahwa sistem antrian dalam keadaan idel. Dalam kondisi ini transisi $s$ tidak bisa aktif sebab walaupun sistem dalam keadaan idel tetapi kondisi di Q kosong/tidak ada yang antri (tidak ada token). Dalam keadaan ini, yang paling mungkin terjadi adalah transisi $a$ yaitu pelanggan datang. Bila hal ini terjadi, maka place $Q$ berisi satu token. Keadaan yang terakhir ini menyatakan bahwa sistem dalam kondisi idel dan sudah ada satu pelanggan yang antri. Oleh karena itu, transisi $s$ bisa terjadi, yaitu server sudah bisa memulai untuk melayani satu pelanggang. Dalam keadaan ini, masing-masing satu token di $B$ dan $Q$ berkurang dan satu token berada di place $B$ (sistem antrian dalam keadaan sibuk).

\section{Model Aljabar maxplus dari Petri net dengan waktu.}

Sebagaimana telah disebutkan dalam bagian sebelumnya, model maxplus aljabar dari petri net dengan waktu untuk sistem antrian sederhana akan dibahas dalam bagian ini. Petri net dalam Gambar 2 bagian (ii) bila dikaitkan dengan waktu akan berubah. Gambar Petri net berikut merupakan gambar dari Petri net dari sistem antrian sederhana yang dikaitkan dengan 
waktu.

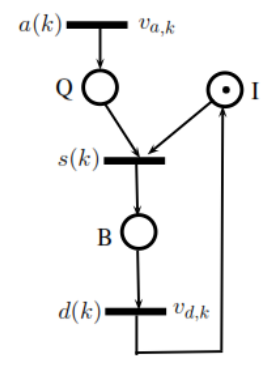

Gambar 3: Sistem pegas

Dalam Gambar 3 ini, bila $a(k)$ menyatakan waktu kedatangan pelanggan saat yang ke- $k, v_{a, k}$ menyatakan lamanya kedatangan pelanggan saat yang ke- $k, s(k)$ menyatakan waktu pelayanan dimulai saat yang ke- $k, d(k)$ menyatakan waktu pelanggan meninggalkan pelayanan saat yang ke- $k$ dan $v_{d, k}$ menyatakan lamanya pelanggan meninggalkan pelayanan saat yang ke$k$, maka didapat

$$
\begin{array}{rlrl}
a(k) & =v_{a, k}+a(k-1), & k=1,2, \ldots \\
s(k) & =\max \{a(k), d(k-1)\}, & k=1,2, \ldots \\
d(k) & =v_{d, k}+s(k), \quad k=1,2, \ldots \\
& =v_{d, k}+\max \{a(k), d(k-1)\} & \\
& =\max \left\{\left(v_{d, k}+v_{a, k}\right)+a(k-1), v_{d, k}+d(k-1)\right\}
\end{array}
$$

Sehingga dengan menggunakan notasi aljabar maxplus didapat persamaan

$$
\left[\begin{array}{l}
a(k) \\
d(k)
\end{array}\right]=\left[\begin{array}{cc}
v_{a, k} & c \\
v_{d, k} \otimes v_{a, k} & v_{d, k}
\end{array}\right] \otimes\left[\begin{array}{c}
a(k-1) \\
d(k-1)
\end{array}\right],
$$

dimana $c$ diplih supaya

$$
\left(v_{a, k} \otimes a(k-1)\right) \oplus(c \otimes d(k-1))=v_{a, k} \otimes a(k-1), \text { untuk } k=1,2,3, \ldots
$$

dan keadaan awal $a(0)=d(0)=0$.

Persamaan (4) adalah bentuk aljabar maxplus dari sistem model antrian dengan satu server dan terlihat bahwa evolusi dari keadaan $a(k)$ dan $d(k)$ 
bergantung pada nilai-nilai dari $v_{a, k}$ dan $v_{d, k}$ untuk $k=1,2,3, \ldots$ Dalam kenyataannya, $v_{a, k}$ dan $v_{d, k}$ adalah barisan bilangan real positip. Sebelum mengakhiri bagian ini, diberikan suatu contoh.

Contoh 3.1 Bila diberikan sample path dari $v_{a, k}$ dan $v_{d, k}$ sebagai berikut

$$
v_{a, k}=\{0.5,0.5,1,0.5,2, \ldots\}, v_{d, k}=\{1,1.5,0.5,0.5,1, \ldots\}
$$

didapat

$$
\begin{gathered}
\left(\begin{array}{l}
a(1) \\
d(1)
\end{array}\right)=\left(\begin{array}{ll}
0.5 & \varepsilon \\
1.5 & 1
\end{array}\right) \otimes\left(\begin{array}{l}
0 \\
0
\end{array}\right)=\left(\begin{array}{l}
0.5 \\
1.5
\end{array}\right) \\
\left(\begin{array}{c}
a(2) \\
d(2)
\end{array}\right)=\left(\begin{array}{cc}
0.5 & \varepsilon \\
2 & 1.5
\end{array}\right) \otimes\left(\begin{array}{l}
0.5 \\
1.5
\end{array}\right)=\left(\begin{array}{l}
1 \\
3
\end{array}\right) \\
\left(\begin{array}{c}
a(3) \\
d(3)
\end{array}\right)=\left(\begin{array}{cc}
1 & \varepsilon \\
1.5 & 0.5
\end{array}\right) \otimes\left(\begin{array}{c}
1 \\
3
\end{array}\right)=\left(\begin{array}{c}
2 \\
3.5
\end{array}\right) \\
\left(\begin{array}{c}
a(4) \\
d(4)
\end{array}\right)=\left(\begin{array}{cc}
0.5 & \varepsilon \\
1 & 0.5
\end{array}\right) \otimes\left(\begin{array}{c}
2 \\
3.5
\end{array}\right)=\left(\begin{array}{c}
2.5 \\
4
\end{array}\right) \\
\left(\begin{array}{c}
a(5) \\
d(5)
\end{array}\right)=\left(\begin{array}{cc}
2 & \varepsilon \\
3 & 1
\end{array}\right) \otimes\left(\begin{array}{c}
2.5 \\
4
\end{array}\right)=\left(\begin{array}{c}
4.5 \\
5.5
\end{array}\right)
\end{gathered}
$$

Dalam hal ini $c=\varepsilon$.

\section{Penutup}

Dalam bagian akhir dari pembahasan paper ini, diberikan beberapa catatan. Model sistem antrian yang dibahas sangat sederhana yaitu antrian hanya dengan satu server, hal ini untuk memberikan suatu ide awal menurunkan model antrian dengan menggunakan aljabar maxplus. Kedepannya kajian bisa diperluas untuk antrian dengan lebih dari satu server, bahkan bila memungkinkan dikaji model antrian yang lebih realistis. Misalnya kapasitas antrian berhingga dan pada saat kondisi tertentu server down 
sehingga memerlukan perbaikan supaya bisa melayani lagi pelanggannya. Untuk kasus ini Petri net dari antrian bentuknya akan berubah dan bagaimana model aljabar maxplusnya bila memungkinkan. Dalam Contoh 3.1 nilai $c$ dipilih $\varepsilon$ (konstan), akibat pemilihan ini matriks model menjadi tidak strongly connected. Bila dikehendaki matriks modelnya menjadi strongly connected, maka pemilihan nilai $c$ adalah bervariasi. Nilai $c$ yang bervariasi, nilai-nilai dari $v_{a, k}$ dan $v_{d, k}$ yang merupakan barisan dari bilangan real positip menyebabkan matriks model yang diperoleh erat kaitannya dengan matriks interval dalam aljabar maxplus.

Model antrian selain disajikan dalam bentuk Petri net, bisa disajikan dalam bentuk apa yang dinamakan automata. Kajian yang telah dibahas mengispirasikan suatu apa yang dinamakan Aljabar Maxplus Automata lewat pendekatan model antrian. Beberapa pembahasan mengenai Aljabar Maxplus Automata didahului dengan suatu model yang dinamakan 'heap'.

\section{Pustaka}

[1] F. Baccelli, G. Cohen, G.J. olsder, and J.-P. Quadrat, 1992, Synchronization and linearity: an algebra for discrete event systems, Wiley.

[2] B. Heidergott, G.J. olsder, and J. van der Woude, 2006, Max Plus at Work Modell ing and Analysis of Synchronized Systems: A Course on Max-Plus Algebra and Its Applications, Princeton University Press

[3] C. Cassandras and S. Lafortune, 1999, Introduction to Discrete Event Systems, Kluwer Academic Publisher.

[4] Subiono, 2000, On classes of min-max-plus systems and their application, $\mathrm{PhD}$ Thesis, Delft University of Technology, the Netherlands.

[5] Subiono and J. van der Woude, 2000, Power Algorithms for (max, + )and bipartite (min,max,+)-systems, Discrete Event Dynamic Systems: Theory and Applications, 10(4):369-389.

[6] Subiono, 2000, Operator linier dalam aljabar max plus dan terapannya, Proceeding SEMINAR NASIONAL MATEMATIKA: Peran Matematika Memasuki Milenium III, ITS-Surabaya. 
[7] Subiono, 2001, Terapan aljabar max-plus pada proses produksiperakitan, Seminar Nasional Matematika, UGM-Jogya.

[8] Subiono, 2002, Pemodelan suatu sistem jaringan kereta dengan menggunakan jadwal keberangkatan kereta, Jounal Natural vol.6, pp.172177.

[9] Subiono, Dieky Adzkiya, 2009, Max-Plus Algebra Toolbox, ver. 1.0.1, Jurusan Matematika ITS, Surabaya. 